\title{
Catalytic Activity and Selectivity of Unsupported Dodecatungstophosphoric Acid, and Its Cesium and Potassium Salts Supported on Silica
}

\author{
Shaimaa M. Ibrahim* \\ Chemistry Department, Faculty of Science, Qassim University, Buraidah, KSA \\ Email: Shiemaa_332003@yahoo.com
}

Received January 24, 2013; revised February 24, 2013; accepted March 20, 2013

Copyright (C) 2013 Sh. M. Ibrahim. This is an open access article distributed under the Creative Commons Attribution License, which permits unrestricted use, distribution, and reproduction in any medium, provided the original work is properly cited.

\begin{abstract}
Potassium and cesium salts of tungstophosphoric acid were prepared by precipitation method. For sake of comparison HPW, potassium and cesium tungstophosphates were supported on silica $(20 \mathrm{wt} \%)$ by wet impregnation method. The catalysts were characterized by XRD, nitrogen adsorption-desorption measurements at $77 \mathrm{~K}$, and the catalytic activity has been studied by using the catalytic conversion of tert-butanol at temperatures between 323 and $423 \mathrm{~K}$. The results revealed that all of the catalysts were active and selective towards dehydration of tert-butanol yielding isobutene with low amount of isooctene as result of oligomerization process. Substitution of one proton of HPW by cesium or potassium cation exerted no measurable effect on the catalytic activity. The conversion over unsupported catalysts increased by increasing the cation content per Keggin unit of $\mathrm{x} \geq 2$. Supporting the previous salts on $\mathrm{SiO}_{2}$ resulted in a significant decrease in the catalytic activity upon increasing cation content. Activation energy was calculated for different solids.
\end{abstract}

Keywords: Tert-Butanol; Supported; Silica; Tungstophosphoric Acid (HPW)

\section{Introduction}

The development of high performance catalysts is very important for chemical technologies. 12-Heteropolyacids with Keggin structures were the objective of research for a long time [1-10]. Heteropolyacids have proved to be the alternative of traditional acid catalysts, such as sulfuric acid and aluminium chloride, due to their strong acidity, environmental benignity and repeated use. But pure HPA used as heterogeneous catalysts were hindered by their low specific area, rapid deactivation and relatively poor stability. However, dodecatungstophosphoric acid is most extensively studied [4,11-18], since it possesses super acidity [19]. Partial exchanging protons of heteropolyacid with large cations, typically demonstrate different physicochemical properties than those of their precursor acids. For example, partial exchanging protons of the parent HPA with large cations, such as $\mathrm{Cs}^{+}, \mathrm{K}^{+}, \mathrm{Rb}^{+}$ and $\mathrm{NH}_{4}^{+}$, which could be water-insoluble and present a rather high surface area [20]. In addition, these heteropolyacid salts improved thermal stability than their parent acids $[5,20]$. Also, these catalysts were tested as

*Permanent address: Chemistry Department, Faculty of Education, Ain Shams University, Roxy, Egypt. catalysts for several reactions with the final objective of industrial use [6,7,21], as alcohol dehydration [8,12,22], alkylation $[9,23]$ or esterification reactions $[18,24]$. The biggest activities were achieved upon partially substitution of HPA protons with Cs stoichiometry for example equal to 2.5. The performance of this catalyst was attributed to its high surface area and its micro- and mesoporous structures $[25,26]$. On the other hand, the BET surface area of cesium dodecatungstophosphate was shown to decrease with increasing the cesium content to 2 [27], leading to a decrease in the activities of these catalysts.

Another method for improving the efficiency of the heteropolyacid catalysts had been achieved by supporting on various carriers as mesoporous silica [17,28,29], aluminosilicates [30], zirconia [11,31] alumina and active carbons $[32,33]$. Because of the basic nature of alumina and zirconia, they led to decomposition of HPA, resulting in a deformation of the parent Keggin structure, thereby reducing the overall activity [11,31]. For supported heteropolyacids, solid state NMR had shown that strong interactions existed between heteropolyacids and their supports, depending on the nature of the support material and the degree of dispersion of heteropolyacid 
[14,34]. When tungstophosphoric acid (HPW) was supported on silica two distinct forms of heteropolyacid are deposited on the surface of silica namely the bulk crystalline phase and the interacting form [35].

The present work aims at investigating the effect of supporting on silica on the textural, catalytic activity and selectivity of $\mathrm{H}_{3} \mathrm{PW}_{12} \mathrm{O}_{40}$ (abbrev, HPW), $\mathrm{Cs}_{\mathrm{x}}$ and $\mathrm{K}_{\mathrm{x}}$ tungstophosphates using the conversion of tert-butanol. The extent of $\mathrm{SiO}_{2}$ was fixed at $20 \mathrm{wt} \%$. Unsupported and silica-supported of $\mathrm{Cs}_{\mathrm{x}}$ and $\mathrm{K}_{\mathrm{x}}$ tungstophosphates were prepared by substituting 1,2 , and 2.5 protons of HPW by cesium or potassium cations. The techniques employed were XRD, $\mathrm{N}_{2}$ adsorption-desorption isotherms carried out at $77 \mathrm{~K}$ and catalytic conversion of tert-butanol over various catalysts at temperatures ranged from 323 to $423 \mathrm{~K}$. The reaction mixture was analyzed using a gas chromatograph.

\section{Experimental}

\subsection{Materials}

Cesium $\left(\mathrm{Cs}_{\mathrm{x}}\right)$ and potassium $\left(\mathrm{K}_{\mathrm{x}}\right)(\mathrm{x}=1,2$, and 2.5$)$ dodecatungstophosphates were prepared by adding dropwise an appropriate volume of aqueous $\mathrm{CsNO}_{3}$ (Aldrich) or $\mathrm{KNO}_{3}$ (Koch-light) to aqueous solution of dodecatungstophosphoric acid (BDH) over a water bath at 343 $\mathrm{K}$ with constant stirring for $4 \mathrm{~h}$. The resulting precipitates were evaporated, dried at $383 \mathrm{~K}$ for $4 \mathrm{~h}$ and calcined at $573 \mathrm{~K}$ for $2 \mathrm{~h}$. Tert-butyl alcohol, (Carlo ERBA) which is chromatographically pure was used.

The silica support material was used for different catalysts having a BET-surface area of ca $645 \mathrm{~m}^{2} / \mathrm{g}$. It was crushed, sieved into grains of $0.2-0.4 \mathrm{~mm}$ and then calcined in a hot-air oven at $773 \mathrm{~K}$ for $4 \mathrm{~h}$. Unsupported $\mathrm{H}_{3} \mathrm{PW}_{12} \mathrm{O}_{40}$ was loaded on silica $(20 \% \mathrm{wt} / \mathrm{wt})$ by wetimpregnation by using a butanolic solution, dried at 383 $\mathrm{K}$ overnight and then calcined at $573 \mathrm{~K}$ for $2 \mathrm{~h}$.

For sake of comparison, the silica-supported cesium and potassium salts of tungstophosphoric acid were prepared by impregnation method adopting the method suggested by Choi et al. [13]. Powdered $\mathrm{SiO}_{2}$ was impregnated by $\mathrm{CsNO}_{3}$ or $\mathrm{KNO}_{3}$ solutions $(20 \% \mathrm{wt} / \mathrm{wt})$, dried at $383 \mathrm{~K}$ overnight, calcined at $573 \mathrm{~K}$ for $2 \mathrm{~h}$. Following this, butanolic solution of tungstophosphoric acid was impregnated followed by drying at $383 \mathrm{~K}$ overnight and calcination at $573 \mathrm{~K}$ for $2 \mathrm{~h}$. The amount of $\mathrm{CsNO}_{3}$ or $\mathrm{KNO}_{3}$ was calculated to have nominal compositions $\mathrm{Cs}_{\mathrm{x}}\left(\mathrm{K}_{\mathrm{x}}\right) \mathrm{H}_{3-\mathrm{x}} \mathrm{PW}_{12} \mathrm{O}_{40}$ (where $\mathrm{x}=1,2$, and 2.5). The obtained catalysts were designated as $\mathrm{HPW}, \mathrm{Cs}_{\mathrm{x}} \mathrm{PW}, \mathrm{K}_{\mathrm{x}} \mathrm{PW}$, $\mathrm{Cs}_{\mathrm{x}} \mathrm{PW} / \mathrm{SiO}_{2}, \mathrm{HPW} / \mathrm{SiO}_{2}$ and $\mathrm{K}_{\mathrm{x}} \mathrm{PW} / \mathrm{SiO}_{2}$.

\subsection{Techniques}

XRD investigation of various prepared solids was carried out using a "Philips" diffractometer type (PW-1390). The patterns were run with $\mathrm{Ni}$-filtered and $\mathrm{Cu}$ radiation $(\lambda=$ $1.5405 \AA$ ) at $40 \mathrm{kV}$ and $40 \mathrm{~mA}$. The scanning rate was fixed at $5^{\circ}$ in $2 \theta / \mathrm{min}$.

Different surface characteristics namely; specific surface area $\left(S_{B E T}\right)$, total pore volume $\left(V_{p}\right)$ and mean pore radius $\left(\mathrm{r}^{-}\right)$of various solids were determined from nitrogen adsorption-desorption isotherms carried out at $77 \mathrm{~K}$ by the conventional volumetric apparatus. Before undertaking such measurements, each sample was degassed under a reduced pressure of $10^{-5}$ Torr for $3 \mathrm{~h}$ at $200^{\circ} \mathrm{C}$. The values of $V_{p}$ were computed from the relation:

$$
V_{p}=15.45 \times 10^{-4} \times V_{s t} \mathrm{~cm}^{3} / \mathrm{g}
$$

where $V_{s t}$ is the volume of nitrogen adsorbed at $\mathrm{P} / \mathrm{P}^{0}$ tends to unity. The values of $\mathrm{r}^{-}$were determined from the equation:

$$
\mathrm{r}^{-}=\frac{2 V_{p}}{S_{B E T}} \times 10^{4} \AA
$$

The catalytic activity of various solids was studied by using the catalytic conversion of tert-Butanol in a conventional flow-type reactor under atmospheric pressure. The reactor tube is a Pyrex glass of $20 \mathrm{~cm}$ long and $1 \mathrm{~cm}$ internal diameter packed with glass beads except in the zone where the catalyst bed is located. The catalyst bed is placed in the middle of the reactor tube. The weight of the catalyst used was $200 \mathrm{mg}$ and a digital thermometer was used to measure the temperature of the catalyst. Both reactor and furnace are placed inside a Pyrex glass jacket of $5 \mathrm{~cm}$ diameter. The catalysts investigated were activated by heating at $573 \mathrm{~K}$ in situ prior to exposure to the alcohol vapor for $1 \mathrm{~h}$ in a current of argon flowing at rate of $20 \mathrm{ml} \cdot \mathrm{min}^{-1}$. The reaction was carried out at temperatures ranged from 323 to $423 \mathrm{~K}$.

The reaction mixture was analyzed using a gas chromatograph (Perkin Elmer Autosystem XL with flame ionization detector) equipped with capillary column (fused silica) of $15 \mathrm{~m}$ length, $0.25 \mathrm{~mm}$ internal diameter, with film thickness $1.0 \mu \mathrm{m}$ the capillary column packed with Carbowax $20 \mathrm{M}$ and the oven temperature set at 333 K. Detector was kept at $493 \mathrm{~K}$.

\section{Results and Discussion}

\subsection{XRD Investigation of Various Solids}

X-ray diffractograms of unsupported acid, its cesium and potassium salts, silica-supported acid and its cesium and potassium salts were determined and illustrated in (Figure 1). The diffractograms of unsupported $\mathrm{K}_{2.5} \mathrm{PW}$ and $\mathrm{Cs}_{2.5} \mathrm{PW}$, not given, are very close to each other and show clearly that the investigated solid exhibited an excellent degree of crystallinity. Supporting HPW on silica (20 wt \%) turned the crystalline acid form (c.f. Figure 1) 


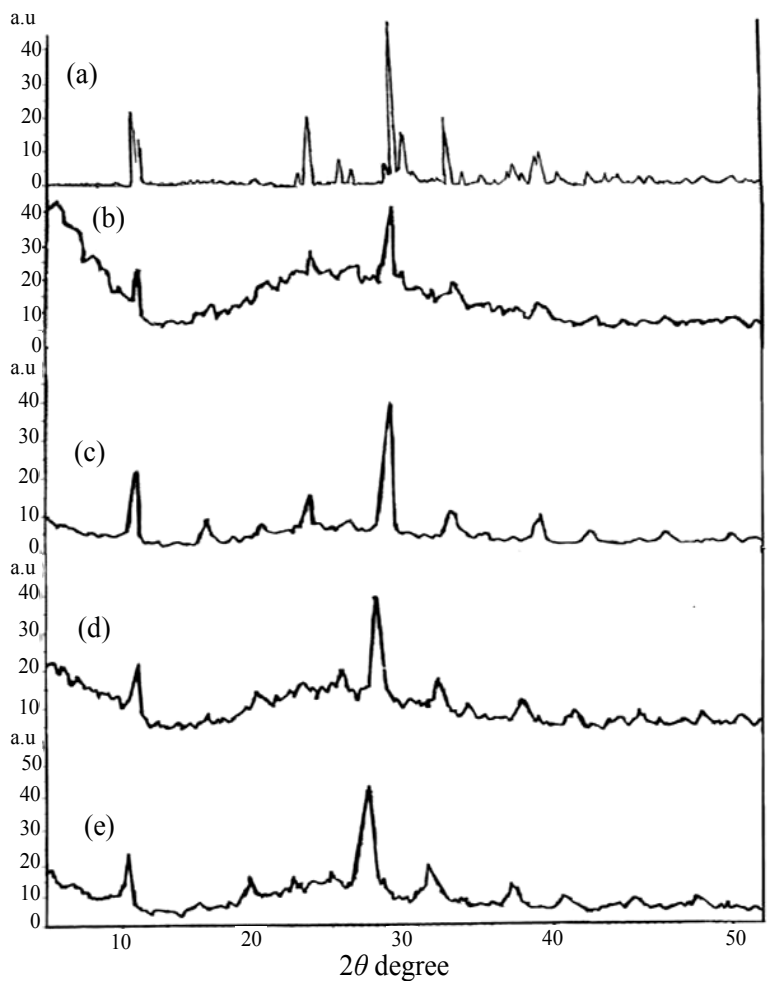

Figure 1. X-ray diffractograms of (a) unsupported HPW; (b) $\mathrm{K}_{1} \mathrm{PW} / \mathrm{SiO}_{2}$; (c) $\mathrm{K}_{2.5} \mathrm{PW} / \mathrm{SiO}_{2}$; (d) $\mathrm{Cs}_{1} \mathrm{PW} / \mathrm{SiO}_{2}$; (e) $\mathrm{Cs}_{2.5} \mathrm{PW} /$ $\mathrm{SiO}_{2}$.

into an amorphous one (figure not given). This finding shows clearly the role of silica in increasing much the degree of dispersion of the acid crystallites measuring very small size below detection limit of X-ray diffractograms $(5 \mathrm{~nm})$. However, the role of silica in turning the acid from crystalline to an amorphous one has been attributed to formation of two dimensional layer due to a strong interaction between HPW and $\mathrm{OH}$ groups on silica according to the following Equation (1) $[8,28]$ :

$$
\mathrm{H}_{3} \mathrm{PW}_{12} \mathrm{O}_{40}+\mathrm{m} \mathrm{OH} / \mathrm{Si} \rightarrow \mathrm{H}_{3-\mathrm{m}} \mathrm{PW}_{12} \mathrm{O}_{40} / \mathrm{Si}+\mathrm{m} \mathrm{H}_{2} \mathrm{O}
$$

This assumption had not been confirmed by other authors $[4,11]$.

It can be also seen from Figure 1 that substitution of one proton of HPW by potassium ion decreased slightly the degree of crystallinity of the supported potassium salts. The relative intensity of all diffraction peaks of acid increased by substituting 2.5 protons by potassium ion but remained having small degree of crystallinity as compared to that of unsupported acid. Furthermore, substitution of 2.5 protons by cesium ions exerted a limited effect on decreasing the degree of crystallinity as compared to the resulting effect observed in case of potassium salts. In conclusion, silica support material turned the crystalline acid into amorphous one and the substitution of one proton of acid by one potassium cation par- tially decreased its degree of crystallinity.

\subsection{Some Textural Characteristics of Selected Adsorbents}

Different surface characteristics namely specific surface area $\left(S_{B E T}\right)$, total pore volume $\left(V_{p}\right)$, and mean pore radius $\left(\mathrm{r}^{-}\right)$of some selected samples were computed from nitrogen adsorption-desorption isotherms obtained at $77 \mathrm{~K}$. Table 1 shows the calculated values of $\left(S_{B E T}\right),\left(V_{p}\right)$, and $\left(\mathrm{r}^{-}\right)$. Examination of Table 1 shows the following: 1) The specific surface area of unsupported HPW increased by supporting on silica (20 $\mathrm{wt} \%$ ) from $7.3 \mathrm{~m}^{2} / \mathrm{g}$ to $542 \mathrm{~m}^{2} / \mathrm{g}$; 2) Substitution of one or two protons of acid in supported solids by corresponding number of potassium and cesium ions decreased progressively the $S_{B E T}$. The maximum decrease attained about $53 \%$ upon the substituting of 2.5 protons by 2.5 potassium or cesium ions; 3) Substitution of proton by cesium or potassium in unsupported acid increased effectively the $S_{B E T}$ and $V_{p}$ of different solids. The increase was, however, more pronounced upon substitution of 2.5 protons by 2.5 potassium or cesium cations. The maximum increase in the $S_{B E T}$ value due to substitution 2.5 protons by 2.5 cesium or potassium ions in unsupported solid salts measured $383 \%$ and $186 \%$, respectively; 4) All investigated adsorbents are considered as mesopores solids. The observed progressive increase in the $S_{B E T}$ due to substitution of acid protons by potassium and cesium cations can be attributed to the resulting progressive decrease in the $\left(\mathrm{r}^{-}\right)$value, which decreased from 47 to $12 \AA$ upon substitution of 2.5 protons of the acid by 2.5 potassium ions.

Table 1. Some surface characteristics for various solid catalysts.

\begin{tabular}{|c|c|c|c|}
\hline Solid & $\mathrm{S}_{\mathrm{BET}} \mathrm{m}^{2} \cdot \mathrm{g}^{-1}$ & $\mathrm{~V}_{\mathrm{P}} \mathrm{ml} \cdot \mathrm{g}^{-1}$ & Mean pore radius, $r$ \\
\hline $\mathrm{SiO}_{2}$ & 645 & - & - \\
\hline HPW & 7.3 & 0.015 & 41 \\
\hline $\mathrm{HPW} / \mathrm{SiO}_{2}$ & 542 & - & - \\
\hline $\mathbf{K}_{1} \mathbf{P W}$ & 11.6 & 0.027 & 47 \\
\hline $\mathbf{K}_{2} \mathbf{P W}$ & 34.1 & 0.042 & 25 \\
\hline $\mathbf{K}_{2.5} \mathbf{P W}$ & 143.3 & 0.089 & 12 \\
\hline $\mathrm{Cs}_{\mathbf{1}} \mathbf{P W}$ & 9.9 & 0.033 & 67 \\
\hline $\mathrm{Cs}_{2} \mathbf{P W}$ & 205 & 0.072 & 70 \\
\hline $\mathrm{Cs}_{2.5} \mathrm{PW}$ & 286.6 & 0.601 & 42 \\
\hline $\mathrm{K}_{1} \mathrm{PW} / \mathrm{SiO}_{2}$ & 268 & - & - \\
\hline $\mathrm{K}_{2} \mathrm{PW} / \mathrm{SiO}_{2}$ & 258 & - & - \\
\hline $\mathrm{K}_{2.5} \mathrm{PW} / \mathrm{SiO}_{2}$ & 250 & - & - \\
\hline $\mathrm{Cs}_{1} \mathrm{PW} / \mathrm{SiO}_{2}$ & 291 & - & - \\
\hline $\mathrm{Cs}_{2} \mathrm{PW} / \mathrm{SiO}_{2}$ & 265 & - & - \\
\hline $\mathrm{Cs}_{2.5} \mathrm{PW} / \mathrm{SiO}_{2}$ & 255 & - & - \\
\hline
\end{tabular}


However, this explanation seems to be not valid in case of unsupported cesium salts. The observed increase in the $S_{B E T}$, and $V_{p}$ of unsupported cesium salts might be attributed to the formation of a good deal of mesopores.

\subsection{Catalytic Properties of Different Solids}

The catalytic conversion of tert-butanol was carried out over various catalysts at temperatures ranged between 323 and $423 \mathrm{~K}$ under a constant partial pressure of alcohol (100 Torr). Preliminary experiments showed that the conversion of alcohol in absence of a catalyst did not take place even for the reaction carried out at $423 \mathrm{~K}$.

Figures 2-4 showed the variation of \% conversion of tert-butanol as function of reaction temperature for various catalysts. It is clear from these figures that the total conversion increases upon increasing the reaction temperature reaching to a constant high value at $373 \mathrm{~K}$ for most of samples investigated.

The reaction products consisted mainly of isobutene together with a small amount of isooctene that may be produced via dimerization of isobutene. However, this reaction took place over various catalysts at temperatures $>373 \mathrm{~K}$. This finding suggested readily that the catalytic conversion of tert-butanol over most catalysts proceeds mainly via dehydration and having selectivity bigger than $90 \%$ at $373 \mathrm{~K}$.

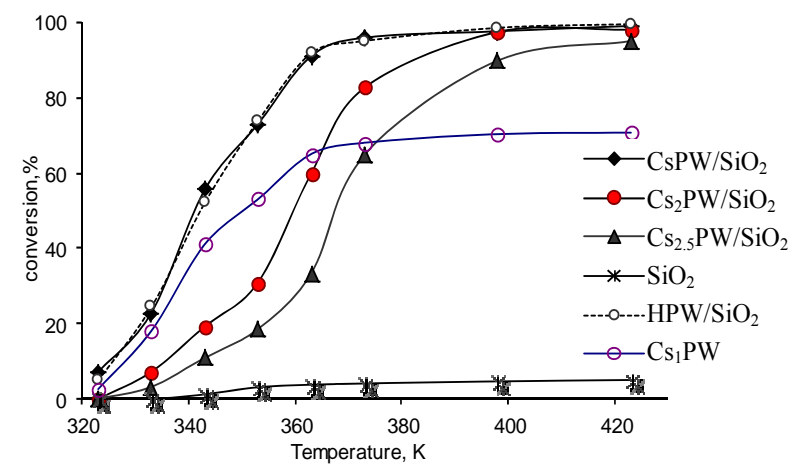

Figure 2. Total conversion, \% of tert-butanol as a function of reaction temperature over prepared catalysts.

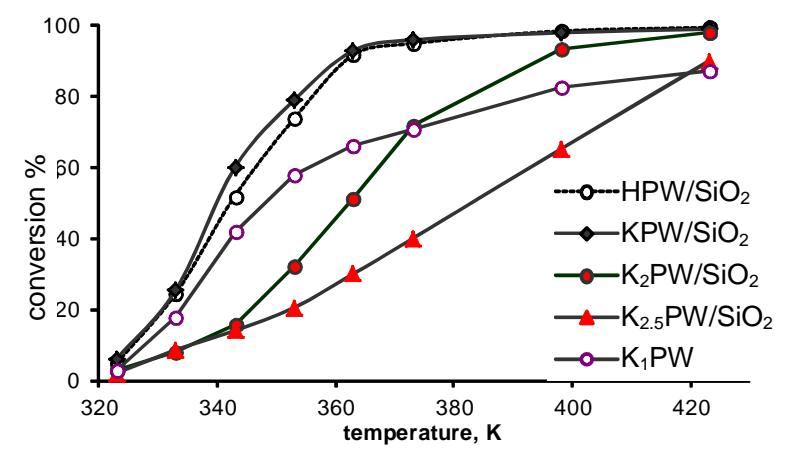

Figure 3. Total conversion, $\mathrm{X} \%$ of tert-butanol as a function of reaction temperature over prepared catalysts.
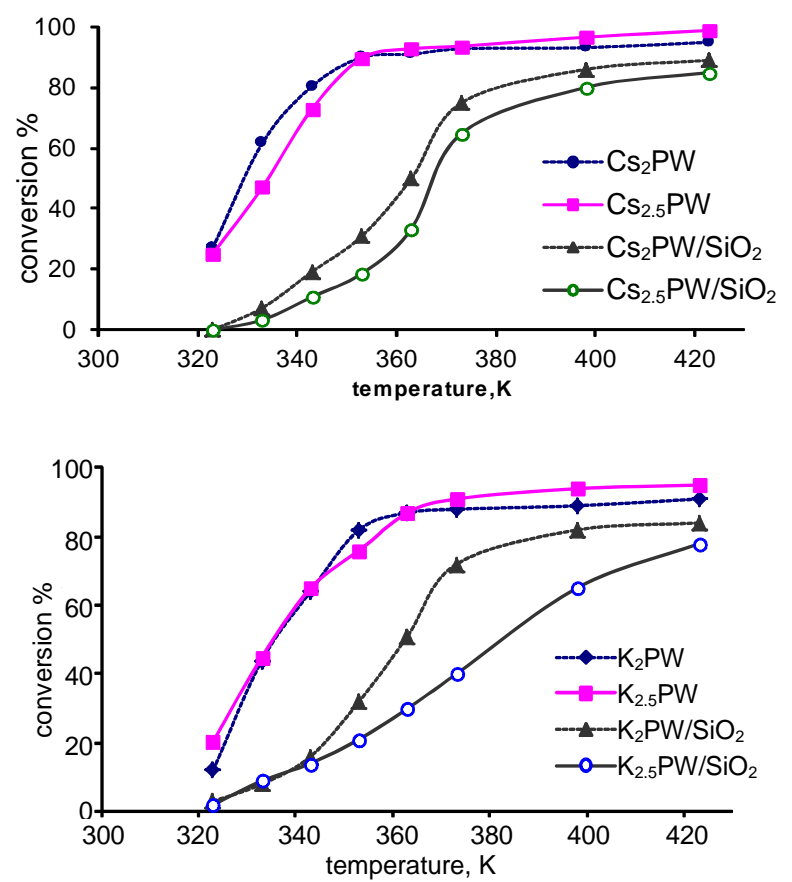

Figure 4. Total conversion, $\mathrm{X} \%$ of tert-butanol as a function of reaction temperature over supported and unsupported catalysts.

Figure 2 showed that the silica support material has very small catalytic activity suggesting its inertness and thus acting as a catalyst support [8,12,36,37].

Examination of Figures 2-4 show the following: 1) Unsupported acid HPW exhibited high catalytic activity and remained very high after being supported on silica; 2) Substitution of one proton of HPW by one cesium or potassium cation in the unsupported catalysts decreased effectively its catalytic performance. This finding might be attributed to very small specific surface area of $\mathrm{Cs}_{1} \mathrm{PW}$ and $\mathrm{K}_{1} \mathrm{PW}$ (c.f. Table 1) and the decrease in the surface acidity due to the formation of cesium and potassium salts of HPW acid. This decrease has been related to the formation of ultrafine precipitate of particles (probably $\mathrm{Cs}_{3} \mathrm{PW}_{12} \mathrm{O}_{40}, 8-10 \mathrm{~nm}$ ) which are thickly covered by $\mathrm{H}_{3} \mathrm{PW}_{12} \mathrm{O}_{40}$, being deposited upon evaporation of water, and form large aggregates, whereby the hydrogen form is possibly acting as cement substrate. After heat treatment they are converted to particles having a similar size as before heat treatment and nearly uniform composition, but with small specific surface area [38,39]; 3) Supporting $\mathrm{Cs}_{1} \mathrm{PW}$ and $\mathrm{K}_{1} \mathrm{PW}$ on silica resulted in increasing the catalytic activity due to an effective increase of the $S_{B E T}$ from 9.9 to $296 \mathrm{~m}^{2} / \mathrm{g}$ for $\mathrm{Cs}_{1} \mathrm{PW}$ and from 11.6 to $268 \mathrm{~m}^{2} / \mathrm{g}$ for $\mathrm{K}_{1} \mathrm{PW}$. This significant increase in the specific surface area is expected to be accompanied by a corresponding increase in the concentration of active sites involved in the catalytic conversion process; 4) Figure 4 shows that the $\%$ alcohol conversion over un- 
supported $\mathrm{K}_{\mathrm{x}}$ and $\mathrm{Cs}_{\mathrm{x}}$ salts of tungstophosphoric acid ( $\mathrm{x}=2$, $2.5)$ decreased by supporting on silica surface. This finding might be attributed to a strong interaction between remained free protons of acid and $\mathrm{OH}$ of silica surface. This interaction may lead to proton transformation to the silica surface which results in a decrease of acidity. In another words, this interaction includes the trapping of some acidic proton in the basic $\mathrm{OH}$ groups of silica support and results in a decrease of the acid strength [14]. So, fewer protons are available for the catalytic reaction.

In order to throw more light on the role of changing the number of protons of the acid by corresponding number of cesium or potassium cations for unsupported and supported salts on silica, the catalytic conversion of tertbutanol measured at $373 \mathrm{~K}$ as being influenced by cation content are illustrated in Figures 5 and 6. It is clearly shown, from Figure 5 that, the catalytic performance of cesium or potassium salts supported on silica decreased progressively by increasing the number of proton of the acid substituted by 2 and 2.5 potassium cations. This decrease is, however, more pronounced in case of potassium salts supported on silica. In fact, the catalytic activity measured at $373 \mathrm{~K}$, of supported cesium salts decreased from $98 \%$ to $70 \%$ and from $98 \%$ to $40 \%$ in case of potassium salts supported on silica.
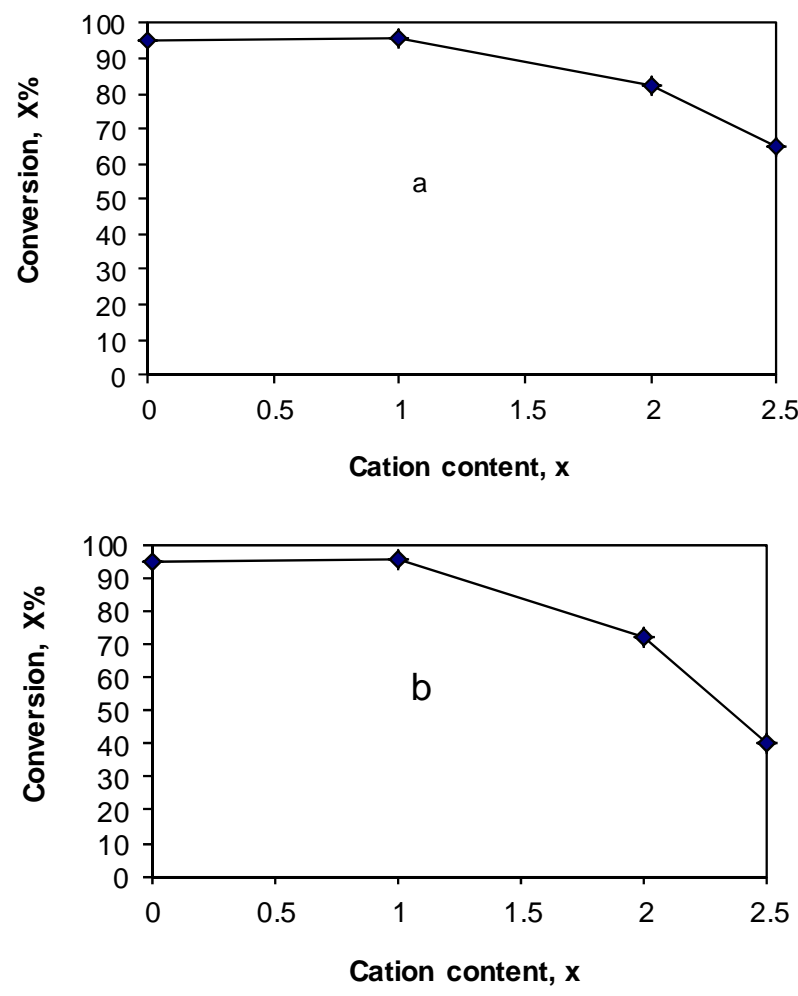

Figure 5. Total conversion, $\mathrm{X} \%$ of tert-butanol at $373 \mathrm{~K}$ as a function of cation content, $\mathrm{X}$ over (a) $\mathrm{Cs}_{\mathrm{x}} \mathrm{PW} / \mathrm{SiO}_{2}$; (b) $\mathrm{K}_{\mathrm{x}} \mathrm{PW} / \mathrm{SiO}_{2}$.

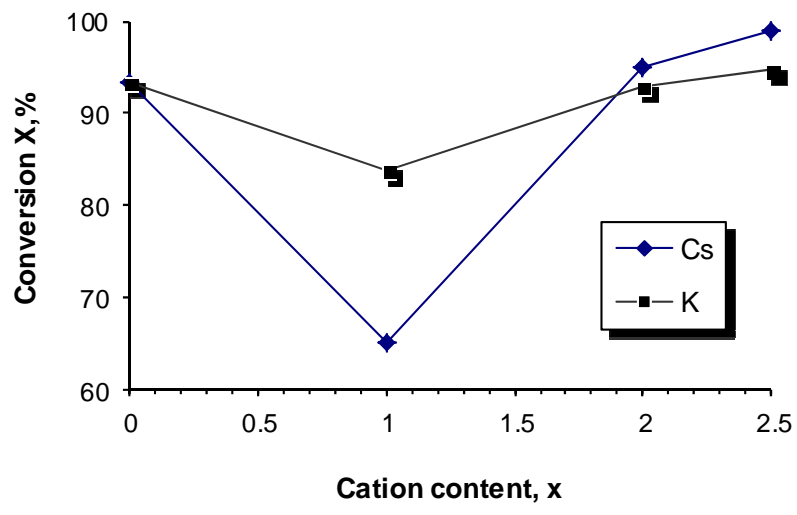

Figure 6. Total conversion $X \%$ of tert-butanol as a function of cation content over acidic salts of tungstophosphoric acid.

However, in case of unsupported cesium and potassium salts of HPW, substitution of one proton by cesium or potassium cation decreased effectively the catalytic activity(c.f. Figure 6), then increased by increasing the number of substituting protons (above one proton) reaching to values near from the values measured for the acid itself. It is interesting to note that, the high activity of $\mathrm{Cs}_{2.5} \mathrm{PW}$ and $\mathrm{K}_{2.5} \mathrm{PW}$ can be correlated with increasing the specific surface area (c.f. Table 1).

The selectivity towards dehydration and dimerization processes during the conversion of tert-butanol, for supported and unsupported solids was measured. The results obtained are listed in Tables 2-4. It is seen from these tables that, the selectivity towards isooctene formation for all catalysts decreases upon increasing substituted protons of tungstophosphoric acid by $\mathrm{Cs}_{\mathrm{x}}$ or $\mathrm{K}_{\mathrm{x}}(\mathrm{x} \geq 2)$ ions (Tables 2-4). This finding might suggest that, these catalysts exhibited very small dimerization selectivity and have small amount of acidic sites on the surface. In previous study, Corma et al [40] reported that the propene oligomerization and n-butane isomerization were correlated with the concentration of protons on the surface. On the other hand, there is no selectivity towards isooctene formation for the $\mathrm{Cs}_{1} \mathrm{PW}$ and $\mathrm{K}_{1} \mathrm{PW}$ catalysts (Table 2). Tables 3 and 4, also show that, $\mathrm{SiO}_{2}$-supported catalysts increased the selectivity towards dimerization processes above $11 \%$ for the reaction carried out at $398 \mathrm{~K}$. These results might be attributed to an effective increase in the ratio of surface polyanion to the bulk polyanion enhancing thus, the selectivity of isooctene formation would increase, on charge of relatively the dehydration to isobutene. But, supporting HPW on silica led to increasing the selectivity towards isooctene formation but small amount not exceeding 4\% (Tables 1 and 3 ).

In order to throw more light on the role of the possible change in the mechanism of catalytic conversion of tertbutanol over various solids, the apparent activation energy $(\Delta \mathrm{E})$ was computed by measuring the reaction rate 
Table 2. Selectivities of unsupported HPW acid and its cesium and potassium salts.

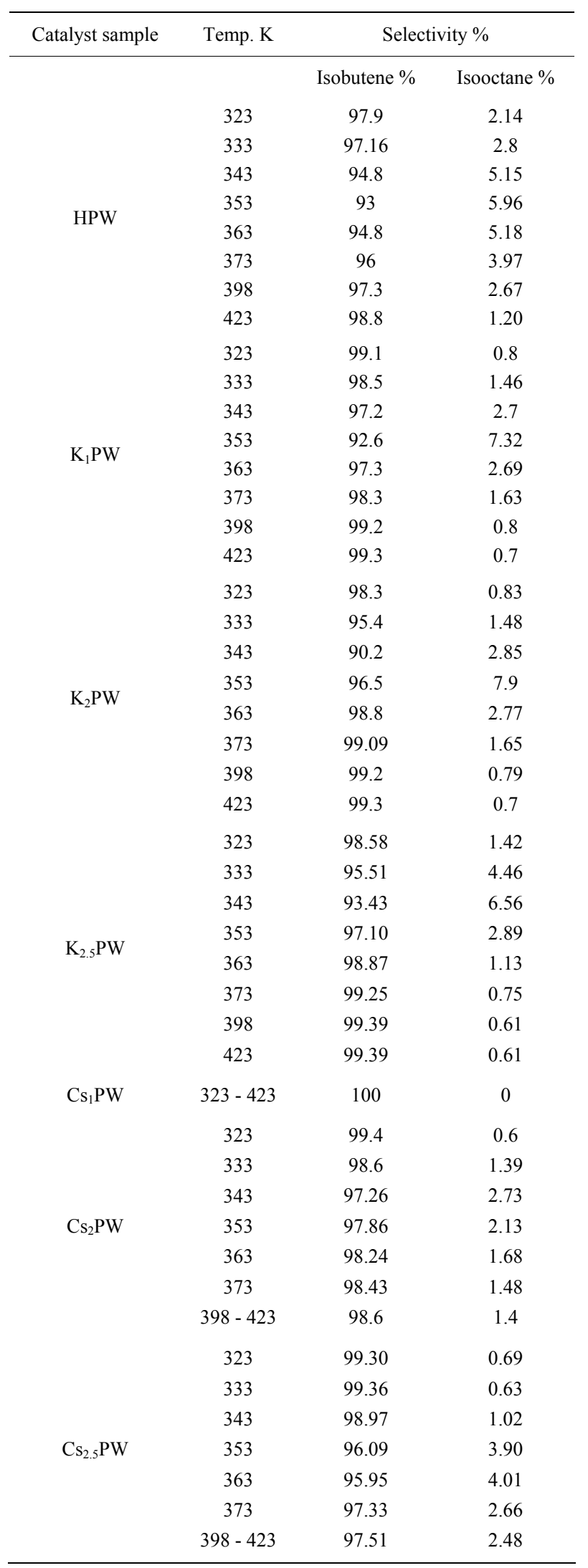

Table 3. Selectivities of $\mathrm{SiO}_{2}$-supported $\mathrm{HPW}$ acid and its potassium salts.

\begin{tabular}{|c|c|c|c|}
\hline \multirow[t]{2}{*}{ Catalyst sample } & \multirow[t]{2}{*}{ Temp. K } & \multicolumn{2}{|c|}{ Selectivity \% } \\
\hline & & Isobutene $\%$ & Isooctane $\%$ \\
\hline \multirow{9}{*}{$\mathrm{HPW} / \mathrm{SiO}_{2}$} & 323 & 100.0 & 0.0 \\
\hline & 333 & 99.2 & 0.8 \\
\hline & 343 & 98.0 & 2.0 \\
\hline & 353 & 98.1 & 1.9 \\
\hline & 363 & 96.4 & 3.6 \\
\hline & 373 & 92.7 & 7.3 \\
\hline & 398 & 83.7 & 16.3 \\
\hline & 423 & 80.9 & 19.1 \\
\hline & 323 & 100.0 & 0.0 \\
\hline \multirow{7}{*}{$\mathrm{K}_{1} \mathrm{PW} / \mathrm{SiO}_{2}$} & 333 & 100.0 & 0.0 \\
\hline & 343 & 100.0 & 0.0 \\
\hline & 353 & 99.5 & 0.5 \\
\hline & 363 & 97.8 & 2.2 \\
\hline & 373 & 93.7 & 6.3 \\
\hline & 398 & 88.8 & 11.2 \\
\hline & 423 & 87.0 & 13.0 \\
\hline \multirow{8}{*}{$\mathrm{K}_{2} \mathrm{PW} / \mathrm{SiO}_{2}$} & 323 & 100.0 & 0.0 \\
\hline & 333 & 100.0 & 0.0 \\
\hline & 343 & 100.0 & 0.0 \\
\hline & 353 & 100.0 & 0.0 \\
\hline & 363 & 100.0 & 0.0 \\
\hline & 373 & 99.4 & 0.6 \\
\hline & 398 & 94.6 & 5.4 \\
\hline & 423 & 88.8 & 11.2 \\
\hline \multirow{8}{*}{$\mathrm{K}_{2.5} \mathrm{PW} / \mathrm{SiO}_{2}$} & 323 & 100.0 & 0.0 \\
\hline & 333 & 100.0 & 0.0 \\
\hline & 343 & 100.0 & 0.0 \\
\hline & 353 & 100.0 & 0.0 \\
\hline & 363 & 100.0 & 0.0 \\
\hline & 373 & 99.8 & 0.2 \\
\hline & 398 & 95.8 & 4.2 \\
\hline & 423 & 91.6 & 8.4 \\
\hline
\end{tabular}

Table 4. Selectivities of $\mathrm{SiO}_{2}$-supported cesium salts of HPW.

\begin{tabular}{cccc}
\hline Catalyst sample & Temp. K & Selectivity $\%$ & \\
\hline & & Isobutene $\%$ & Isooctane \% \\
& 323 & 100.0 & 0.0 \\
& 333 & 99.3 & 0.7 \\
& 343 & 99.2 & 0.8 \\
$\mathrm{Cs}_{1} \mathrm{PW} / \mathrm{SiO}_{2}$ & 353 & 99.0 & 1.0 \\
& 363 & 97.8 & 2.2 \\
& 373 & 95.3 & 4.7 \\
& 398 & 86.1 & 13.9 \\
& 423 & 80.8 & 19.2 \\
& 323 & 100.0 & 0.0 \\
& 333 & 100.0 & 0.0 \\
& 343 & 100.0 & 0.0 \\
$\mathrm{Cs}_{2} \mathrm{PW} / \mathrm{SiO}_{2}$ & 353 & 100.0 & 0.0 \\
& 363 & 99.7 & 0.3 \\
& 373 & 99.3 & 0.7 \\
& 398 & 95.7 & 4.3 \\
& 423 & 91.6 & 8.4 \\
& 323 & 100.0 & 0.0 \\
& 333 & 100.0 & 0.0 \\
& 343 & 100.0 & 0.0 \\
$\mathrm{Cs}_{2.5} \mathrm{PW} / \mathrm{SiO}_{2}$ & 353 & 100.0 & 0.0 \\
& 363 & 100.0 & 0.0 \\
& 373 & 99.7 & 0.3 \\
& 398 & 97.8 & 2.2 \\
& 423 & 92.6 & 7.4 \\
\hline
\end{tabular}


constant $(k)$ at temperatures between 323 and $423 \mathrm{~K}$ and by direct application of the Arrhenius equation via plotting of $\ln k$ versus $1 / T$ (figures, not given). The computed $\Delta \mathrm{E}$ values are given in Table 5. Examination of Table 5 shows that $\Delta \mathrm{E}$ values for unsupported and supported solids ran in parallel to the observed change in the catalytic activity (i.e. high catalytic activity measured small $\Delta \mathrm{E}$ values and vice versa). In order to throw more light on the possible heterogeneity of surfaces of the investigated catalysts, the values of $\ln A$ (pre-exponential factor of the Arrhenius equation) were calculated for unsupported solids and those supported on silica $20 \mathrm{wt} \%$ and the data obtained are given in Table 5. It is shown from this Table 5 that $\ln \mathrm{A}$ values are close to each other within the experimental error $\left( \pm 0.5 \mathrm{~kJ} \cdot \mathrm{mol}^{-1}\right)$. This finding might express the possible change of the mechanism of catalytic reaction.

\section{Conclusions}

The following are the main conclusions that may be drawn from the results obtained:

1) Loading HPW on silica ( $20 \mathrm{wt} \%$ ) turned the crystalline acid into amorphous one indicating an effective increase of the degree of dispersion. However, this process increased considerably the $S_{B E T}$ of $\mathrm{SiO}_{2}$-supported HPW;

2) Unsupported solids, substituting 2.5 protons of acid by $2.5 \mathrm{Cs}$ or $\mathrm{K}$ cations increased the degree of crystallinity of the solid. $\mathrm{K}_{2.5} \mathrm{PW}$ and $\mathrm{Cs}_{2.5} \mathrm{PW}$ samples have the maximum value of $S_{B E T}$ as compared to the other unsupported catalysts;

3) Supporting of $\mathrm{K}_{x} \mathrm{PW}$ and $\mathrm{Cs}_{\mathrm{x}} \mathrm{PW}(\mathrm{x}=1-2.5)$ on $\mathrm{SiO}_{2}$ decreased the degree of crystallinity of the investigated solids. This decrease was, however, more pronounced in case of cesium salts of HPW;

4) The $S_{B E T}$ of the supported Cs or K salts of HPW increased progressively by increasing the number of protons substituted by cesium or potassium cations;

5) Unsupported and silica supported HPW, cesium and

Table 5. Apparent activation energies for tert-butanol con version over different catalysts.

\begin{tabular}{cccccc}
\hline Catalyst & $\mathrm{E}_{\mathrm{a}}\left(\mathrm{kJ}^{\left.\mathrm{m} \cdot \mathrm{mol}^{-1}\right)}\right.$ & $\mathrm{Ln} \mathrm{A}$ & Catalyst & $\mathrm{E}_{\mathrm{a}}\left(\mathrm{kJ} \cdot \mathrm{mol}^{-1}\right)$ & $\mathrm{Ln} \mathrm{A}$ \\
\hline $\mathrm{HPW}$ & 17.0 & -4.4 & $\mathrm{HPW} / \mathrm{SiO}_{2}$ & 11.5 & -4.2 \\
$\mathrm{Cs}_{1} \mathrm{PW}$ & 17.5 & -4.6 & $\mathrm{Cs}_{1} \mathrm{PW} / \mathrm{SiO}_{2}$ & 10.3 & -4.2 \\
$\mathrm{Cs}_{2} \mathrm{PW}$ & 7.8 & -4.3 & $\mathrm{Cs}_{2} \mathrm{PW} / \mathrm{SiO}_{2}$ & 30.6 & -4.4 \\
$\mathrm{Cs}_{2.5} \mathrm{PW}$ & 6.9 & -4.3 & $\mathrm{Cs}_{2.5} \mathrm{PW} / \mathrm{SiO}_{2}$ & 32.4 & -4.6 \\
$\mathrm{~K}_{1} \mathrm{PW}$ & 20.8 & -4.7 & $\mathrm{~K}_{1} \mathrm{PW} / \mathrm{SiO}_{2}$ & 11.5 & -4.2 \\
$\mathrm{~K}_{2} \mathrm{PW}$ & 7.9 & -4.3 & $\mathrm{~K}_{2} \mathrm{PW} / \mathrm{SiO}_{2}$ & 36.2 & -4.5 \\
$\mathrm{~K}_{2.5} \mathrm{PW}$ & 7.0 & -4.3 & $\mathrm{~K}_{2.5} \mathrm{PW} / \mathrm{SiO}_{2}$ & 39.0 & -4.6 \\
\hline
\end{tabular}

potassium salts of HPW exhibited an excellent catalytic performance and acting as dehydrating catalyst for tertbutanol;

6) Substitution of one proton of HPW by one Cs or K cation in the unsupported catalysts decreased effectively its catalytic performance. But, supporting $\mathrm{Cs}_{1} \mathrm{PW}$ and $\mathrm{K}_{1} \mathrm{PW}$ on silica resulted increasing in the catalytic activity due to an effective increase in the $S_{B E T}$;

7) On the other hand, the catalytic activity of unsupported $\mathrm{K}_{\mathrm{x}}$ and $\mathrm{Cs}_{\mathrm{x}}$ salts of HPW $(\mathrm{x}=2,2.5)$ decreased by supporting on silica surface. This might be attributed to a strong interaction between remained free protons of acid and $\mathrm{OH}$ of silica surface;

8) The catalytic activity and selectivity towards dehydration and dimerization processes of the unsupported and supported catalysts are much affected by the number of substituted acid protons by alkali metal.

\section{Acknowledgements}

The author thanks Prof Dr. Gamil Ali El-Shobaky for his revision of the manuscript and his valuable comments.

\section{REFERENCES}

[1] J. H. Sepúlveda, J. C. Yori and C. R. Vera, "Repeated Use of Supported $\mathrm{H}_{3} \mathrm{PW}_{12} \mathrm{O}_{40}$ Catalysts in the Liquid Phase Esterification of Acetic Acid with Butanol," Applied Catalysis A: General, Vol. 288, No. 1, 2005, pp. 18-24. doi:10.1016/j.apcata.2005.03.038

[2] M. Misono, "A View on the Future of Mixed Oxide Catalysts: The Case of Heteropolyacids (Polyoxometalates) and Perovskites," Catalysis Today, Vol. 100, No. 1-2, 2005, pp. 95-100. doi:10.1016/j.cattod.2004.12.010

[3] K. N. Rao, K. M. Reddy, N. Lingaiah, I. Suryanarayana and P. S. Saiprasad, "Structure and Reactivity of Zirconium Oxide-Supported Ammonium Salt of 12-Molybdophosphoric Acid Catalysts," Applied Catalysis A: General, Vol. 300, No. 2, 2006, pp. 139-146. doi:10.1016/j.apcata.2005.10.051

[4] W. Kuang, A. Rives, M. Fournier and R. Hubaut, "Structure and Reactivity of Silica-Supported 12-Tungstophosphoric Acid," Applied Catalysis A: General, Vol. 250, No. 2, 2003, pp. 221-229. doi:10.1016/S0926-860X(03)00239-4

[5] T. Okuhara, N. Mizuno and M. Misono, "Catalytic Chemistry of Heteropoly Compounds," Advances in Catalysis, Vol. 41, 1996, p. 113. doi:10.1016/S0360-0564(08)60041-3

[6] I. V. Kozhevinkov and K. I. Matveev, "Homogeneous Catalysts Based on Heteropoly Acids," Applied Catalysis A: General, Vol. 5, No. 2, 1983, p. 135. doi:10.1016/0166-9834(83)80128-6

[7] A. N. Kharat, Ph. Pendleton, A. Badalyan, M. Abedini and M. M. Amini, "Oxidation of Aldehydes Using Silica-Supported Co(II)-Substituted Heteropolyacid," Journal of Molecular Catalysis A: Chemical, Vol. 175, No. 


\section{1-2, 2001, pp. 277-283.}

[8] Y. Izumi, R. Hasebe and K. Urabe, "Catalysis by HeteroGeneous Supported Heteropoly Acid," Journal of Catalysis, Vol. 84, No. 2, 1983, p. 402. doi:10.1016/0021-9517(83)90011-8

[9] M. Misono, "Recent Progress in the Practical Applications of Heteropoly Acid and Perovskite Catalysts: Catalytic Technology for the Sustainable Society," Catalysis Today, Vol. 144, No. 3-4, 2009, pp. 285-291.

[10] B. Bachiller-Baeza and J. A. Anderson, "FTIR and ReacTion Studies of the Acylation of Anisole with Acetic Anhydride over Supported HPA Catalysts," Journal of Catalysis, Vol. 228, No. 1, 2004, pp. 225-233. doi:10.1016/j.jcat.2004.08.010

[11] E. López-Salinas, J. G. Hernández-Cortéz, I. Schifter, E. Torres-Garcia, J. Navarrete, A. Gutiérrez-Carrillo, T. López, P. P. Lottici and D. Bersani, "Thermal Stability of 12-Tungstophosphoric Acid Supported on Zirconia," Applied Catalysis A: General, Vol. 193, No. 1, 2000, pp. 215-225. doi:10.1016/S0926-860X(99)00431-7

[12] J. Haber, K. Pamin, L. Matachowski, B. Napruszews and J. Poltowicz, "Potassium and Silver Salts of Tungstophosphoric Acid as Catalysts in Dehydration of Ethanol and Hydration of Ethylene," Journal of Catalysis, Vol. 207, No. 2, 2002, pp. 296-306. doi:10.1006/jcat.2002.3514

[13] S. Choi, Y. Wang, Z. Nie, J. Liu and C. H. F. Peden, "Cs-Substituted Tungstophosphoric Acid Salt Supported on Mesoporous Silica," Catalysis Today, Vol. 55, No. 1, 2000, pp. 117-124. doi:10.1016/S0920-5861(99)00231-X

[14] J. H. Kim, Y. G. Shul and H. Han, "Synthesis of Heteropolyacid $\left(\mathrm{H}_{3} \mathrm{PW}_{12} \mathrm{O}_{40}\right) / \mathrm{SiO}_{2}$ Nanoparticles and Their Catalytic Properties," Applied Catalysis A: General, Vol. 299, No. 1, 2006, pp. 46-51. doi:10.1016/j.apcata.2005.10.010

[15] J. Haber, K. Pamin, L. Matachowski and D. Mucha, "Catalytic Performance of the Dodecatungstophosphoric Acid on Different Supports," Applied Catalysis A: General, Vol. 256, No. 1, 2003, pp. 141-152. doi:10.1016/S0926-860X(03)00395-8

[16] S. Soled, S. Miseo, G. McVicker, W. E. Gates, A. Gutierrez and J. Paes, "Preparation of Bulk and Supported Heteropolyacid Salts," Catalysis Today, Vol. 36, No. 4, 1997, pp. 441-450. doi:10.1016/S0920-5861(96)00235-0

[17] A. Alsalme1, E. F. Kozhevnikova and I. V. Kozhevnikov, " $\alpha$-Pinene Isomerisation over Heteropoly Acid Catalysts in the Gas-Phase," Applied Catalysis A, Vol. 390, No. 1-2, 2010, pp. 219-224.

[18] S. K. Bhorodwaj and D. K. Dutta, “Activated Clay Supported Heteropoly Acid Catalysts for Esterification of Acetic Acid with Butanol," Applied Clay Science, Vol. 53, No. 2, 2011, pp. 347-352. doi:10.1016/j.clay.2011.01.019

[19] T. Okuhara, T. Nishimura and M. Misono, "Novel MiCroporous Solid 'Super Acids': $\mathrm{Cs}_{\mathrm{x}} \mathrm{H}_{3-\mathrm{x}} \mathrm{PW}_{12} \mathrm{O}_{40}(2 \leq \mathrm{x} \leq$ 3)," 11th International Congr. Catal., Baltimore, 1996, p. 581.

[20] T. Okuhara, T. Nishimura, H. Watanabe, K. Na and M. Misono, "Catalysis of Cesium Salt of Heteropoly Acid and Its Characterization by Solid-State NMR," Studies in Surface Science and Catalysis, Vol. 90, 1994, pp. 419428. doi:10.1016/S0167-2991(08)61853-4

[21] C. Travers, E. Essayem, M. Delage and S. Quelen, "Heteropolyanions Based Catalysts for Paraffins Isomerization," Catalysis Today, Vol. 65, No. 2-4, 2001, pp. 355361. doi:10.1016/S0920-5861(00)00590-3

[22] A. Alhanash, E. F. Kozhevnikova and I. V. Kozhevnikov, "Gas-Phase Dehydration of Glycerol to Acrolein Catalysed by Caesium Heteropoly Salt," Applied Catalysis A, Vol. 378, No. 1, 2010, pp. 11-18.

[23] W. Yang, J. Billy, Y. B. Taârit, J. C. Védrine and N. Essayem, " $\mathrm{H}_{3} \mathrm{PW}_{12} \mathrm{O}_{40}$ Supported on Cs Modified Mesoporous Silica: Catalytic Activity in n-Butane Isomerisation and in Situ FTIR Study: Comparison with Microporous $\mathrm{Cs}_{\mathrm{x}} \mathrm{H}_{3-\mathrm{x}} \mathrm{PW}_{12} \mathrm{O}_{40}$, Catalysis Today, Vol. 73, No. 1-2, 2002, pp. 153-165. doi:10.1016/S0920-5861(01)00508-9

[24] L. R. Pizzio and M. N. Blanco, "Isoamyl Acetate Production Catalyzed by $\mathrm{H}_{3} \mathrm{PW}_{12} \mathrm{O}_{40}$ on Their Partially Substituted Cs or K Salts," Applied Catalysis A: General, Vol. 255, No. 2, 2003, pp. 265-277. doi:10.1016/S0926-860X(03)00565-9

[25] M. A. Parent and J. B. Moffat, "Cation/Proton Interactions and Acid Strengths in Salts of 12-Tungstophosphoric Acid Prepared from 1A, 1B and 3B Monovalent Cations," Catalysis Letters, Vol. 48, No. 3-4, 1997, pp. 135-143. doi:10.1023/A:1019012128507

[26] J. G. Highfield and J. B. Moffat, "Elucidation of the Mechanism of Dehydration of Methanol over 12-Tungstophosphoric Acid Using Infrared Photoacoustic Spectroscopy," Journal of Catalysis, Vol. 95, No. 1, 1985, pp. 108-119. doi:10.1016/0021-9517(85)90012-0

[27] M. Mizuno and M. Misono, "Heterogeneous Catalysis," Chemical Reviews, Vol. 98, No. 1, 1998, pp. 199-218. doi:10.1021/cr960401q

[28] Sh. M. Ibrahim and G. A. El-Shobaky, "Catalytic Efficiency of Cesium and Potassium Salts of Dodecatungstophosphoric Acid Supported on Silica and Comparison with $\mathrm{H}_{3} \mathrm{PW}_{12} \mathrm{O}_{40} / \mathrm{SiO}_{2}$," Kinetics and Catalysis, Vol. 49, No. 4, 2008, pp. 507-515. doi:10.1134/S0023158408040058

[29] I. V. Kozhevnikov, K. R. Kloestra, A. Sinnema, H. W. Zandbergen and H. Van Bekkum, "Study of Catalysts Comprising Heteropoly Acid $\mathrm{H}_{3} \mathrm{PW}_{12} \mathrm{O}_{40}$ Supported on MCM-41 Molecular Sieve and Amorphous Silica," Journal of Molecular Catalysis A: Chemical, Vol. 114, No. 1-3, 1996, pp. 287-298. doi:10.1016/S1381-1169(96)00328-7

[30] T. Blasco, A. Corma, A. Martinez and P. Martinez-Escolano, "Supported Heteropolyacid (HPW) Catalysts for the Continuous Alkylation of Isobutane with 2-Butene: The Benefit of Using MCM-41 with Larger Pore Diameters," Journal of Catalysis, Vol. 177, No. 2, 1996, pp. 306-313. doi:10.1006/jcat.1998.2105

[31] K. Saita, M. Nomura, S. Ohgoshi and Y. Akai, "Symposium on Solid Super Acids: Synthesis, Characterization and Catalysis," Proceedings of the 214th National Meeting, Nevada, 7-11 September 1997.

[32] Z. Zhao, W. Ahn and R. Ryoo, "Preparation, Charac- 
terization and Catalytic Activity of Heteropolyacids Supported on Mesoporous Silica and Carbon," Studies in Surface Science and Catalysis, Vol. 146, 2003, pp. 657-660. doi:10.1016/S0167-2991(03)80469-X

[33] L. R. Pizzio, C. V. Caceres and M. N. Blanco, "Acid Catalysts Prepared by Impregnation of Tungstophosphoric Acid Solutions on Different Supports," Applied Catalysis A: General, Vol. 167, No. 2, 1998, pp. 283-294. doi:10.1016/S0926-860X(97)00328-1

[34] M. M. Mastikhin and S. M. Timofeeva, " $\mathrm{H}$ and ${ }^{31} \mathrm{P}$ MAS NMR Studies of Solid Heteropolyacids and $\mathrm{H}_{3} \mathrm{PW}_{12} \mathrm{O}_{40}$ Supported on $\mathrm{SiO}_{2}$," Journal of Molecular Catalysis, Vol. 60 , No. 1, 1990, pp. 65-70. doi:10.1016/0304-5102(90)85068-S

[35] F. Lefebvre, “31 P MAS NMR Study of $\mathrm{H}_{3} \mathrm{PW}_{12} \mathrm{O}_{40}$ Supported on Silica: Formation of $\left(\mathrm{SiOH}_{2}^{+}\right)\left(\mathrm{H}_{2} \mathrm{PW}_{12} \mathrm{O}_{40}{ }^{-}\right)$," Journal of the Chemical Society, Chemical Communications, No. 10, 1992, pp. 756-757. doi:10.1039/c39920000756

[36] J. B. Moffat and S. Kasztelan, "The Oxidation of Methane on Heteropolyoxometalates II. Nature and Stability of the Supported Species," Journal of Catalysis, Vol. 109, No. 1, 1988, pp. 206-211. doi:10.1016/0021-9517(88)90199-6
[37] C. Rocchiccioli-Deltcheff, M. Amirouche, G. Herve, M. Fournier, M. Che and J. M. Tatibouet, "Structure and Catalytic Properties of Silica-Supported Polyoxomolybdates: II. Thermal Behavior of Unsupported and SilicaSupported 12-Molybdosilicic Acid Catalysts from IR and Catalytic Reactivity Studies," Journal of Catalysis, Vol. 126, No. 2, 1990, pp. 591-599. doi:10.1016/0021-9517(90)90022-C

[38] K. Na, T. Iizaki, T. Okuhara and M. Misono, "Molecular Design of Solid Acid Catalysts. Isomerization of n-Butane Catalyzed by Acidic Cesium Salts of 12-Tungstophosphoric Acid Combined with Platinum," Journal of Molecular Catalysis, Vol. 115, No. 3, 1997, pp. 449-455. doi:10.1016/S1381-1169(96)00350-0

[39] G. Koyano, K. Ueno and M. Misono, "Three Types of Acid Catalysis in Liquid Phase of Metal Salts of 12-Tungstophosphoric Acid, $\mathrm{Mn}_{+\mathrm{x}} \mathrm{H}_{3-\mathrm{nx}} \mathrm{PW}_{12} \mathrm{O}_{40}$," Applied $\mathrm{Ca}$ talysis A, Vol. 181, 1999, p. 267.

[40] A. Corma, A. Martinez and C. Martinez, "Acidic $\mathrm{Cs}^{+}$, $\mathrm{NH}_{4}^{+}$, and $\mathrm{K}^{+}$Salts of 12-Tungstophosphoric Acid as Solid Catalysts for Isobutane/2-butene Alkylation," Journal of Catalysis, Vol. 164, No. 2, 1996, pp. 422-432. doi:10.1006/jcat.1996.0398 